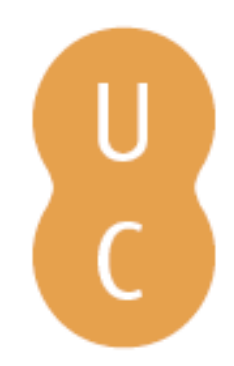

\title{
nombalina
}

\section{Garnering green energy from granites: lessons and opportunities from a UK perspective}

\author{
Autor(es): $\quad$ Stephens, William \\ Publicado por: Imprensa da Universidade de Coimbra; Laboratório de Radioactividade \\ Natural da Universidade de Coimbra \\ URL \\ persistente: URI:http://hdl.handle.net/10316.2/36290 \\ DOI: $\quad$ DOI:http://dx.doi.org/10.14195/978-989-26-1009-2_3 \\ Accessed : $\quad$ 26-Apr-2023 12:23:21
}

A navegação consulta e descarregamento dos títulos inseridos nas Bibliotecas Digitais UC Digitalis, UC Pombalina e UC Impactum, pressupõem a aceitação plena e sem reservas dos Termos e Condições de Uso destas Bibliotecas Digitais, disponíveis em https://digitalis.uc.pt/pt-pt/termos.

Conforme exposto nos referidos Termos e Condições de Uso, o descarregamento de títulos de acesso restrito requer uma licença válida de autorização devendo o utilizador aceder ao(s) documento(s) a partir de um endereço de IP da instituição detentora da supramencionada licença.

Ao utilizador é apenas permitido o descarregamento para uso pessoal, pelo que o emprego do(s) título(s) descarregado(s) para outro fim, designadamente comercial, carece de autorização do respetivo autor ou editor da obra.

Na medida em que todas as obras da UC Digitalis se encontram protegidas pelo Código do Direito de Autor e Direitos Conexos e demais legislação aplicável, toda a cópia, parcial ou total, deste documento, nos casos em que é legalmente admitida, deverá conter ou fazer-se acompanhar por este aviso. 


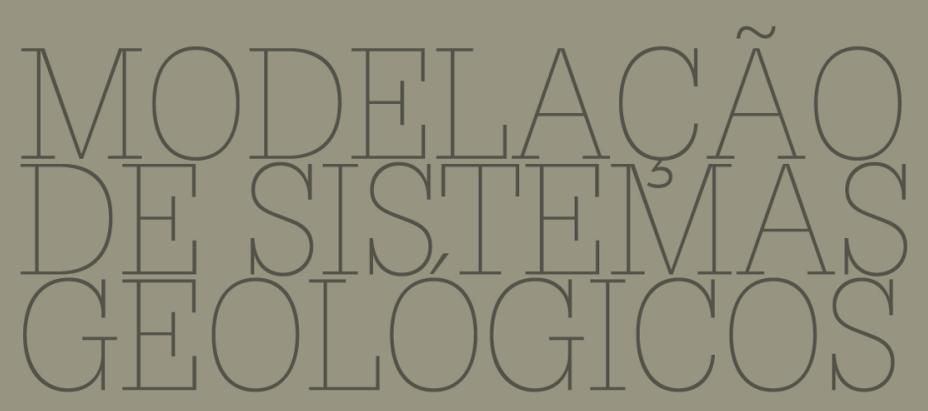

Homenagem ao Professor Doutor Manuel Maria Godinho

L.J.P.F. Neves, A.J.S.C. Pereira,

C.S.R. Gomes, L.C.G. Pereira,

A.O. TAVARES

IMPRENSA DA UNIVERSIDADE DE COIMBRA

CoImBra University Press 


\title{
MODELAÇÃO \\ DE SISTEMAS \\ GEOLÓGICOS
}

Homenagem ao Professor Manuel Maria Godinho

\section{Garnering green energy from granites: Lessons and opportunities from a UK perspective}

\author{
William Stephens ${ }^{1}$ \\ ${ }^{1}$ Department of Earth Sciences, University of St Andrews, St Andrews, Fife KY16 9AL, UNITED \\ KINGDOM, Ed.Stephens@st-andrews.ac.uk
}

Key-words: Granite, Geothermal energy, Scotland

\begin{abstract}
The concept of extracting geothermal energy from hot granitic rock sources at depths of 35 kilometres is enjoying a renaissance as a practical concept, and several prospects worldwide are under development. It is noteworthy however that very few hot rock prospects are being developed at latitudes affected by Pleistocene glaciation. Here we examine three regions of high heat producing granites in the United Kingdom that were located either beneath thick ice (Eastern Grampian Highlands of Scotland, North of England) or beyond the ice limit (Cornubia). Heat flow measurements made in 30 relatively shallow boreholes and mines ( $\leq 300$ metres) do not correlate well with heat production as estimated from the concentrations of radiothermal elements, with anomalously low heat flow values restricted to boreholes located in areas covered by Pleistocene ice sheets. Maximum ice sheet thickness is estimated using a model of glacio-isostatic rebound and used as a proxy for the magnitude of the glacial cooling and inter-glacial warming effects on near-surface heat flow. No significant correlation is observed between measured heat flow and heat generation despite all areas having large negative Bouguer gravity anomalies indicating thick batholithic masses of granite underlying all boreholes. However a strong correlation is observed between heat flow and maximum ice thickness suggesting this is a primary control on present day heat flow at shallow levels. A deep borehole is required to test this hypothesis. The geochemistry of these high heat producing granites in Scotland is examined and their potassic and fractionated characteristics are used to show that other plutons in Scotland may share their heat generating potential. It is concluded that the East Grampian batholith in Scotland may have been mistakenly excluded as a region of hot rock geothermal potential, and its inclusion would add significantly to the UK's hot rock resources. If this is a generic feature of glaciated terrains then many more hot resources may be hitherto unidentified in the higher latitudes of the northern hemisphere.
\end{abstract}




\section{Introduction}

A scientific consensus has emerged that combustion of fossil fuels is contributing to long-term changes in the planet's climate system. The EU is committed to reducing greenhouse gas emissions relative to 1990 levels and the UK has set a reduction target of at least $80 \%$ by 2050 (anon 2010). This means installing considerable renewable energy capacity and the UK's strategic priority is to exploit its extensive onshore and offshore wind resources while developing new technologies for utilising wave and tidal resources. Policy-makers presently envisage only a minor role for geothermal energy in the power generating mix by 2050 (anon 2010). In other countries such as Germany the potential of deep, radiothermal granites to fill some of the impending heat and power gap has been recognised, and overcoming the considerable technological challenges in exploiting these resources is being viewed as a major market opportunity (Nitsch 2008). Increasing costs of fossil fuels, the need to reduce emissions and pressures to secure indigenous energy supplies combine to bring the geothermal option into consideration.

The partitioning of $\mathrm{K}, \mathrm{U}$ and $\mathrm{Th}$ by silicic magmas and further concentration by fractional crystallisation provides the geochemical basis for high heat producing granites (HHP), radioactive decay being the principal source of deep hot rock geothermal energy in crustal rocks (MIT 2006). HHP granites are typically uranium-rich and promising hot rock resources usually generate $5-10 \mu \mathrm{W} / \mathrm{m}^{3}$ through radioactive decay. High enthalpy fluids $\left(>150^{\circ} \mathrm{C}\right)$ can be extracted in a closed loop by injecting cold fluids from the surface through an engineered facture system in hot rocks at depth and returning steam or hot fluid to the surface to drive a turbine (MIT 2006). Such enhanced (or engineered) geothermal systems provide the basis for optimism that geothermal energy sources may be available for exploitation in many continental regions with no proximity to volcanic activity. [Note that the descriptors hot fractured rock (HFR) and enhanced geothermal system (EGS) are technically more correct but hot dry rock (HDR) is in common usage.]

It has been three decades since the first HDR project at Fenton Hill (Los Alamos, USA) but large-scale generation of power at commercial cost from HDR sources has eluded available technologies. A breakthrough came in 2009 following a proof-of-concept test at Innamincka in the Cooper Basin in South Australia where a reservoir was stimulated at $4.25 \mathrm{~km}$ depth in rocks at $247^{\circ} \mathrm{C}$ between two wells some 560 metres apart. The closed loop test over six weeks successfully demonstrated fluid circulation between the 
injection and production wells (Wyborn 2010). The Cooper Basin resource appears to be colossal. The operators, Geodynamics Ltd, recently submitted evidence to the Australian Government stating that "there is in the order of $10,000 \mathrm{MW}$ of long term, emission free, baseload generation capacity that can be economically extracted from the company's tenements in the Cooper Basin" (Geodynamics 2009). For comparison, this is a quantity well in excess of the present total electricity usage in Scotland or Portugal.

The aim of this paper is to re-examine the data on which the EGS potential of northerly regions of the UK was judged to be limited, and to interpret measured heat flow patterns in granites in the context of glacialinterglacial geothermal patterns. Elsewhere in northern Europe it has been clearly demonstrated that post-Pleistocene geothermal gradients formerly under thick ice sheets terrain have not yet reached a steady state and heat flow estimated from gradients derived from shallow boreholes can very significantly underestimate present-day heat flow at depth. Data used to evaluate the UK potential in the 1980s are here re-examined in this light and the geothermal potential reconsidered.

\section{Heat generation and heat flow in UK granites}

Following the oil crises of the 1970s the UK (and later the EU) developed a major programme of research into its indigenous geothermal resources. Here we consider only the deep geothermal resources of the UK, all associated with HHP granites. The programme concluded that three regions hosted interesting HHP granites (Wheildon and Rollin 1986), namely Devon and Cornwall in SW England (Cornubia), the Lake District and Co Durham (N.England), and the eastern Grampian Highlands of Scotland (E.Grampians) (Figure1). Comparison of the heat flow in these regions, however, indicated major differences in geothermal potential (Lee 1986). (Note that all heat flow estimates for the N.England and E.Grampians are taken from boreholes typically 300 metres deep whereas those in the Cornubian granites are more typically 100 metres deep although the values broadly coincide with much deeper estimates from the South Crofty and Geevor mines in the Land's End and Carnmenellis plutons respectively.)

Bodies of HHP granite can be identified by modelling the heat production of rock samples from their concentrations of $\mathrm{U}$, Th and $\mathrm{K}$. The granites of interest in this study are of Caledonian age (about 390-430 Ma) in Scotland and N.England, and Hercynian (290-260 Ma) in Cornubia. Heat production values for representative samples of Scottish granites have been 
calculated using data from our own laboratories as well as the literature. The data indicate that most HHP granites are located in the east of Scotland, primarily in the eastern Grampian Highlands (Figure 1) in a group of plutons collectively termed the Cairngorm Suite (Stephens and Halliday 1984) and found from Cairngorm (Figure 1) eastwards. Four plutons, namely Cairngorm, Ballater, Bennachie and Mount Battock, were investigated in detail.

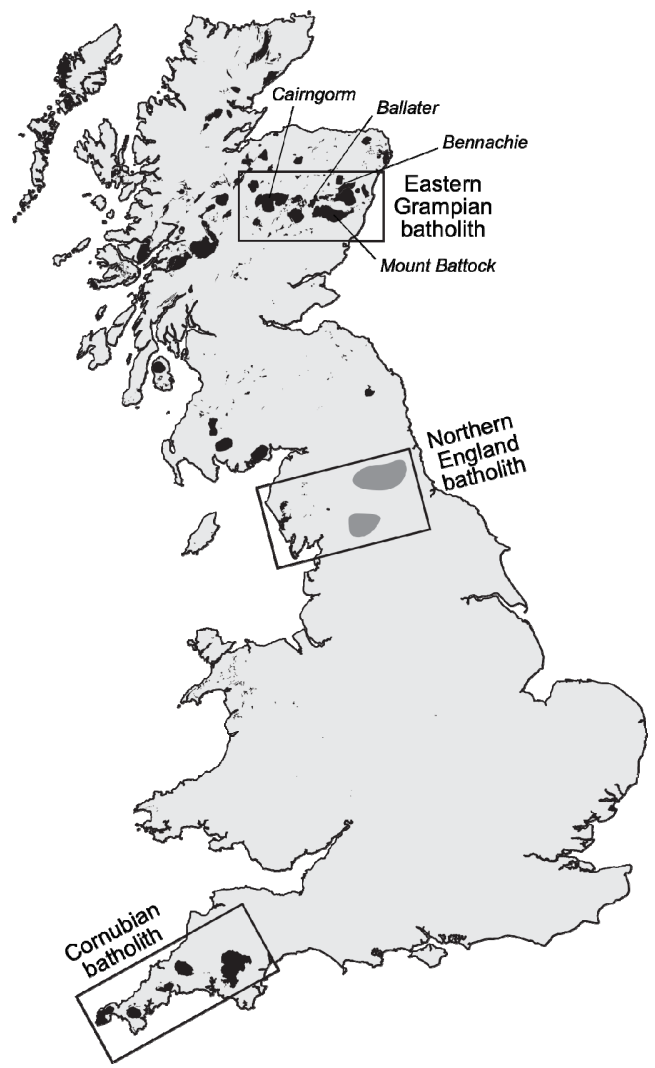

Figure 1. Map of the locations of the main batholithic areas with containing heat producing granites. Negative gravity anomalies underlie all three batholiths. Black areas are granite bodies and dark grey areas are granite plutons identified by gravity anomalies. Four plutons in the Eastern Grampian batholith discussed in the text are indicated.

The Cairngorm Suite granites of the eastern Grampian Highlands have a mean heat production of $6.0 \mu \mathrm{W} / \mathrm{m}^{3}$ (standard deviation 2.2), and many fall in the range of the Big Lake granodiorite underlying the Cooper Basin, 
calculated to produce $7-10 \mu \mathrm{W} / \mathrm{m}^{3}$ (Beardsmore 2005). This is currently regarded the best large-scale EGS prospect in the world, producing water temperatures during circulation tests in 2009 ranging from $212^{\circ} \mathrm{C}$ at the wellhead to $244^{\circ} \mathrm{C}$ at the bottom of the hole (Wyborn 2010). Another major project at Soultz (France) in the Rhine graben has granitic source rocks with heat production calculated to range between $2-5 \mu \mathrm{W} / \mathrm{m}^{3}$. Indeed most of the Cairngorm Suite samples significantly exceed the heat production of the granites of Cornubia and N.England (means of 4.6 and $4.1 \mu \mathrm{W} / \mathrm{m} 3$ respectively), the former regarded as one of the best EGS prospects in the European Union. These comparisons suggest that Scotland may have some large granite plutons suitable for high enthalpy EGS and thus power generation.

The E.Grampian (Cairngorm Suite) granites are generally high heat producing but this is not matched by elevated levels of measured heat flow. This apparent contradiction accounts for the low level of interest in these granites as potential geothermal resources (Wheildon, King et al. 1984). There are various explanations for this paradox, including:

- That the granites are present as shallow sheets rather than thick plutons, leading to a much smaller volumetric contribution than the areal distribution of granite outcrops might suggest.

- That the actinides are heterogeneously distributed with uranium in particular concentrated nearer the surface where the survey samples were collected, perhaps redistributed by hydrothermal processes.

- That there are large differences in heat flow from the mantle and crustal basement rocks beneath the granites, with the basement in Scotland (north of the major Iapetus suture line representing the accretion of the Avalonian microcontinent to Laurentia) having significantly lower heat flow than the basement beneath the N.England and Cornubian granites.

None of these explanations fully accounts for the major observed differences in heat flow. The evidence of negative Bouguer gravity anomalies suggests that a deep batholith ("East Highlands batholith") underlies the HHP granites of the E.Grampians region to a depth of $13 \mathrm{~km}$ (Lee 1986), rather than sheets. Investigation of surface samples and those from boreholes indicates that accessory minerals are often important primary repositories of actinides but there is some grain boundary redistribution of uranium and uraninite is also present. Some leaching of 
uranium might be expected in near-surface samples and so the estimates used here, based on bulk analyses of surface samples, are considered likely to be underestimates of the radioelement concentrations in deep rocks (Webb and Brown 1984), but the depth profile of heat producing elements is not know with any certainty. As for variations in mantle and deep crustal sources, the area-weighted amplitude of the UK-wide background, omitting measurements made in granite areas, is estimated as $52 \pm 9 \mathrm{~mW} / \mathrm{m}^{2}$ (Wheildon and Rollin 1986). Comparison of this figure with the heat flow map of the UK does not indicate any major difference between the background heat flows in Scotland, N.England and Cornubia. As the difference between the heat flows in HHP granites of Cornubia and Scotland is of the same order this factor alone is only likely to make a small contribution. Overall, these factors do not appear to account for the magnitude of difference between those HHP that generate high heat flows and those that do not. An alternative possible explanation is considered below.

\section{Influence of Late Pleistocene glaciation}

It has been known for a very long time that protracted glaciation has a significant effect on measured temperatures in boreholes, with greatest effects closest to the surface and discernible down to about two kilometres (Benfield 1939). Evidence from careful measurements in very deep boreholes indicates that heat flow estimates in terrain formerly beneath thick ice sheets are transient and may be significantly affected by changes in surface temperatures. Estimates on long-term heat flow only become reliable below about 2 kilometres depth (Majorowic, Safanda et al. 2008). Recently such perturbations has been extensively modelled to retrieve climate change information, and the unreliability of heat flow estimates in northerly latitudes has been highlighted (Majorowicz and Wybraniec 2010). In extreme cases such as Sidorowka-Udryn in Poland the gradient of temperature with depth is zero and even negative within the top several hundred metres of the borehole.

It is noteworthy that the sequence of low through intermediate to high heat flow plutons in the UK HHP granites follows an approximately N-S regional trend from Scotland through N.England to Cornubia. This prompts the question as to whether this also reflects a glacial-interglacial transition pattern. Late Pleistocene glaciation strongly affected much of the UK but the effects did not extend as far south as the Cornubian granites and are 
concentrated in Scotland and upland areas of Wales and England (Clark, Evans et al. 2004; Fretwell, Smith et al. 2008). The UK may represent a microcosm of a European-wide ice margin effect following the last glaciation (Majorowicz and Wybraniec 2010). The current published map of heat flow in Europe has very few areas of high heat flow north latitude $50^{\circ} \mathrm{N}$; even Iceland has a modest heat flow of about $60 \mathrm{~mW} / \mathrm{m}^{2}$ (Hurtig, Cermak et al. 1992). A new map which attempts to model the glacialinterglacial effects on heat flow applies corrections up to about $20 \mathrm{~mW} / \mathrm{m}^{2}$ (Majorowicz and Wybraniec 2010) and generates a much less polarised distribution, suggesting that some reasonably high heat flow regions do indeed exist in northerly latitudes. The observed heat flow difference between the E.Grampian and Cornubian granites is of the order of 50 $\mathrm{mW} / \mathrm{m}^{2}$ (Figure $2 \mathrm{a}$ ), somewhat larger than the typical $20 \mathrm{~mW} / \mathrm{m}^{2}$ correction applied by the model (Majorowicz and Wybraniec 2010) and much greater than the $5-10 \mathrm{~mW} / \mathrm{m}^{2}$ suggested by the 1980 s study of the UK's geothermal potential (Wheildon and Rollin 1986).

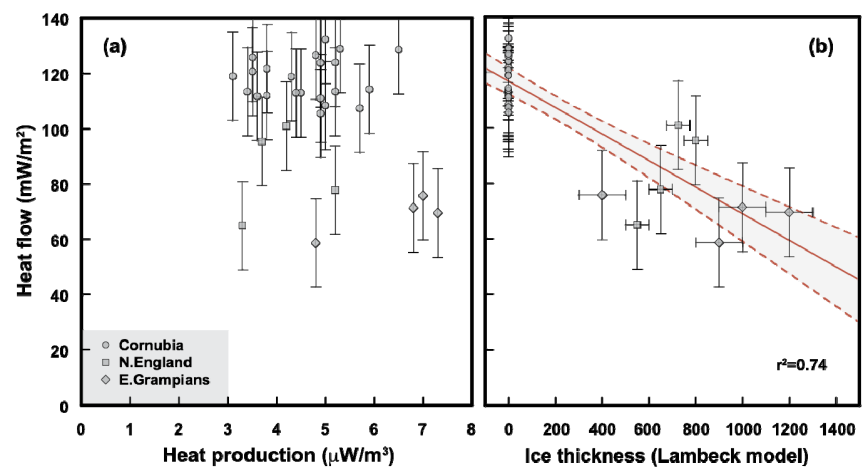

Figure 2. (a) Relationship between calculated heat production and heat flow in boreholes within granites located in three regions of the UK (Cornubia, N.England and E.Grampian Highlands of Scotland). (b) Comparison of heat flow with ice thickness during late Pleistocene glaciation over the UK (regression line significant at $\rho<0.001$ ). Ice thicknesses derived from the model of Lambeck [17].

The UK offers an opportunity to examine the relationship between apparent heat flow in relatively shallow ( $\leq 300$ metres) boreholes and Pleistocene glaciation over a traverse from more than a kilometre of ice sheet to unglaciated terrain within broadly the same lithology, namely high 
heat producing granites. Heat flow data obtained from thirty 100-300 metre boreholes in granites from the E.Grampian, N.England and Cornubian batholiths (Figure 3) were taken from a compilation of UK boreholes (Lee 1986). Because of its very high heat flow (often $120 \mathrm{~mW} / \mathrm{m}^{2}$ ) the Cornubian batholith is well represented with 22 boreholes, the other two regions have four boreholes each. As a proxy of the magnitude of the glacial effect the 1995 glacio-isostatic rebound model of Lambeck is adopted in this study (Lambeck 1995). Maximum ice thickness values were derived by subtracting terrain elevation from the Lambeck model of ice surface elevation (Fretwell, Smith et al. 2008), and thickness contours are shown on figure 3. Ice thicknesses at each borehole location were estimated from this map.

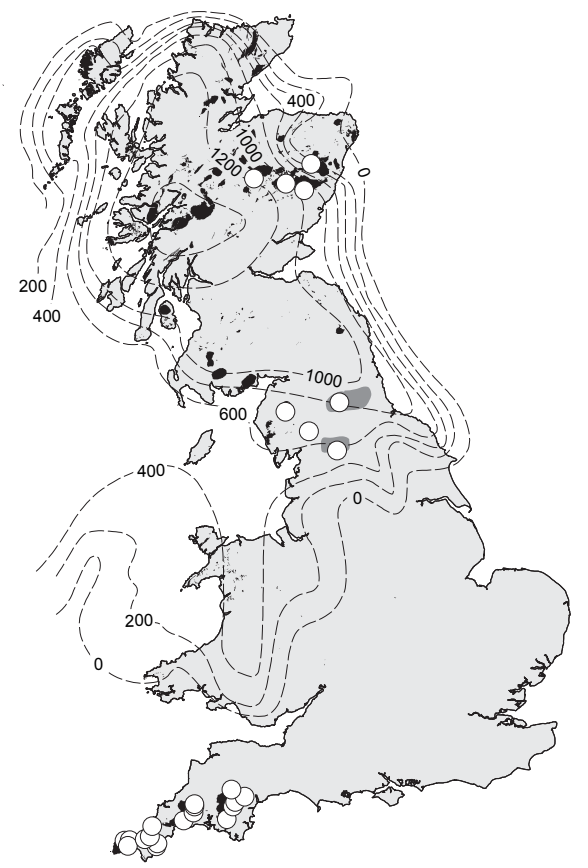

Figure 3. Map showing the locations of the boreholes used in this study (white circles) and contours of maximum ice thickness during Pleistocene glaciation from Lambeck (1995) [17] used to estimate ice thickness over each borehole.

The most important factors that determine heat flow in thick granitic plutons are heat production that can be modelled using measured concentrations of $\mathrm{U}, \mathrm{Th}$ and $\mathrm{K}$ in samples obtained from surface outcrops or cores, and heat flow from beneath the pluton. In order to explore the 
possibility that the glaciation effect is important regression analyses of the dependence of heat flow on heat production and ice thickness was undertaken. It is assumed that the measured heat flows used in the study are due to conductive heat transfer and have not been disturbed by fluid circulation (quality selection was applied in the original datasets). A single value for heat flow, heat production and ice thickness is used to represent each borehole in this analysis. This approximation is justified on grounds that radioelement decay is the dominant source of heat in HHP granites of batholithic proportions (Pollack 1982) and the study aims to identify the major controls on the geographical variation in heat flow in shallow boreholes within broadly similar HHP granites, rather creating an accurate model of heat flow at individual sites.

Figure $2 \mathrm{a}$ shows that there is no significant correlation between heat production and heat flow between the different granite regions of the UK. In contrast ice thickness does a significant inverse relationship with heat flow $(\rho<0.001)$ (Figure 2b). Thus there is a strong suggestion in the data that the ice sheet effect is real and that heat flow estimates within glacial terrains may reflect transient conditions and provide significant underestimates of steady state heat flow. Confidence in this outcome comes from knowing that the results conform to a well-established pattern of reduced apparent heat flow in the regions of Pleistocene ice sheets in the northern hemisphere (Majorowicz and Wybraniec 2010).

While this analysis oversimplifies a complex set of relationships, the results suggest that glaciation has reduced current estimates of heat flow in the N.England and E.Grampian regions, probably significantly in excess of the $20 \mathrm{~mW} / \mathrm{m}^{2}$ typical for northern Europe (Majorowicz and Wybraniec 2010). If this is correct then the decision not to prospect for hot rock geothermal resources in the HHP granites of the E.Grampians of Scotland (Wheildon, King et al. 1984) in favour of the HHP granites of England would appear premature and may have overlooked a significant potential resource.

Numerical modelling indicates that this transient glacial-interglacial effect extends to around 2 kilometres depth and persists for approximately twenty thousand years after melting (Majorowic, Safanda et al. 2008). Thus estimates of heat flow in terrain affected by ice sheets during the Pleistocene and deglaciated in the Holocene are likely to be strongly affected, especially in boreholes of the depths used in this study ( $\leq 300$ metres). 


\section{Reassessment of the geothermal potential of the Scottish granites}

This analysis suggests that high heat producing granites associated with low heat flow in the northern regions of the UK should be re-examined. Most of the HHP granites in northern England are concealed and were discovered on the basis of strong negative gravity anomalies and proved by drilling. Scotland however has a large number of exposed plutons some of which may be candidates for geothermal systems. As well as the four plutons shown on figure 1 there may be other granites among the Scottish plutons that have HHP characteristics. To examine this possibility a database of whole rock compositions of the Caledonian Newer Granite plutons in Scotland was compiled from in-house analyses and the literature.

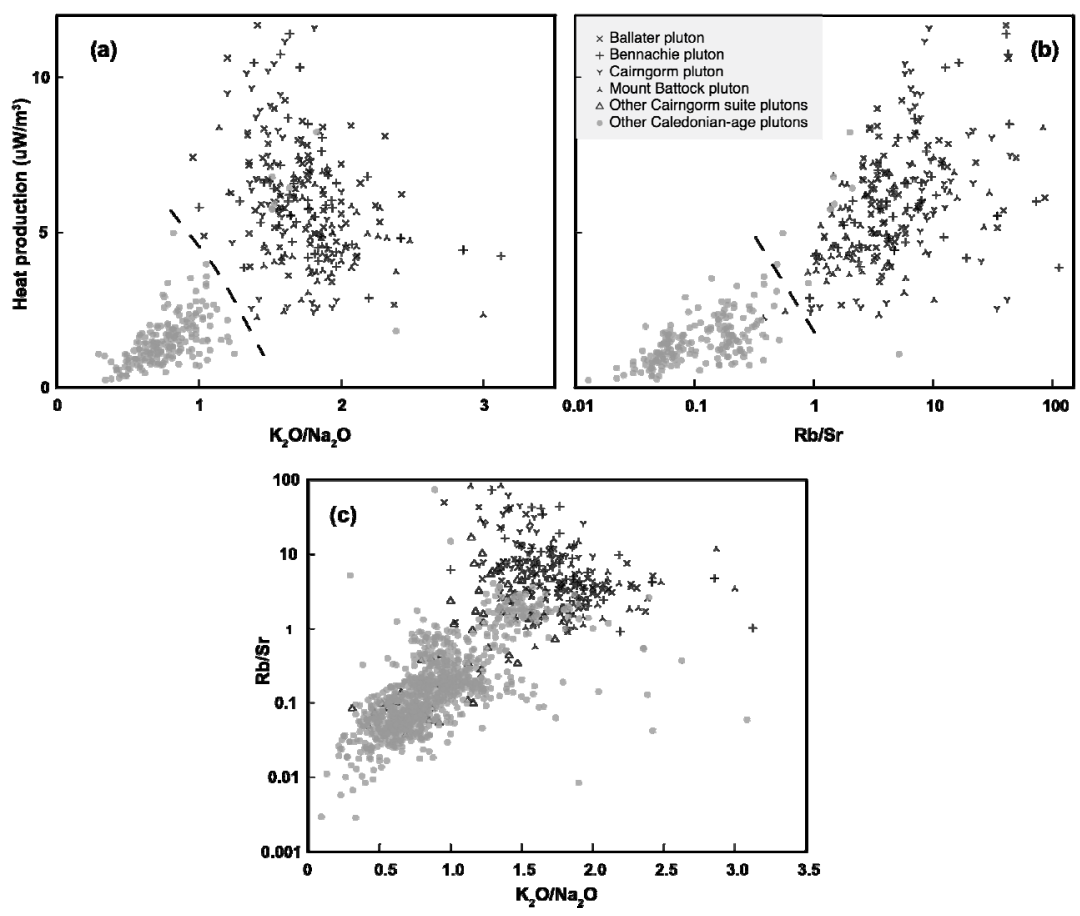

Figure 4. (a) and (b) Heat Production as a function of $\mathrm{K}_{2} \mathrm{O} / \mathrm{Na}_{2} \mathrm{O}$ and $\mathrm{Rb} / \mathrm{Sr}$ respectively in plutons for which accurate radioelement data are available. These whole rock ratios are effective at discriminating the HHP plutons of Ballater, Bennachie, Cairngorm and Mt Battock, separated from non-radiothermal granites by the dashed line. (c) Application of these ratios to a much larger dataset including other plutons within the Cairngorm suite and other suites within the Caledonian Newer Granites of Scotland [8] with the aim of identifying other possible HHP plutons. Key for all diagrams shown in (b). 
A subset of samples in the dataset includes analyses of the radioactive elements from which heat generation was calculated, and the bulk characteristics of these samples were examined for geochemical features that typify the Scottish HHP granites. These HHP granites tend to be rich in $\mathrm{SiO}_{2}$, and in mineralogical and geochemical terms they have bulk characteristics typical of I-type granites, with high field strength element abundances overlapping into A-types. Figure 4a shows that they are also notably potassic in terms of the alkalinity ratio $\left(\mathrm{K}_{2} \mathrm{O} / \mathrm{Na}_{2} \mathrm{O}\right) . \mathrm{Rb} / \mathrm{Sr}$ is usually taken as an indicator of fractional crystallisation, and figure $4 \mathrm{~b}$ shows this parameter on a logarithmic scale indicating that these HHP granites in Scotland are strongly fractionated.

Applying both parameters to the full dataset results figure 4c shows that many other granites plutons, both within the Cairngorm suite of the E.Grampians and elsewhere in Scotland, have the same highly potassic fractionated granite characteristics of those known to be high heat producers. There is also a complementary group of plutons that are devoid of these features and are very unlikely to be capable of supporting geothermal systems.

It is particularly important to test the model for HHP granites developed above, particularly the explanation of the heat production-heat flow paradox. If the explanation is correct then Scotland may escape the ranks of the geothermally barren. Testing would require drilling a borehole up to two kilometres deep, and if successful there is the potential of adding a new province of approximately the same size of the Cornubian province to the inventory of national hot dry rock geothermal resources.

\section{Conclusions}

1. This work supports a growing awareness that good hot rock geothermal prospects may be overlooked in terrains that have been under Pleistocene ice sheets if evaluation is based entirely on heat flow obtained from shallow boreholes.

2. Anomalies in the relationship between heat generation and heat flow are highlighted, and heat flow is frequently lower than predicted from heat generation (but never higher).

3. These negative heat flow anomalies lie exclusively at locations that lay beneath thick ice sheets in the late Pleistocene, and most measurements in these areas share this feature. 
4. High heat producing granites in Scotland have a distinctive potassic and fractionated geochemistry. This can be used as a predictive tool to identify other plutons with geothermal potential as well as those without such potential.

5. If the concept of systematic underestimation of heat flow in heavily glaciated regions is demonstrated in the east of Scotland by deep boreholes then a large new region may be added to the UK's potential hot dry rock resources.

The era of hydrocarbon-based energy dominance is coming to an end, and we are embarking on a new era of technological exploitation of emissionfree energy sources. Geology can make a major contribution through geothermal energy extracted from radiothermal granites at depth. The technology is highly challenging but rapidly developing. The potential resources are considerable and widespread, unlike volcanic sources of geothermal energy that are effectively restricted to plate boundaries. It is important that the locations of useful resources are identified so that the energy may be garnered as soon as the technology becomes available and the commercial environment conducive. Of all the "green" energy sources available, geothermal is almost unique in its zero carbon emissions, low environmental footprint and capability of supplying baseload power regardless of climatic conditions.

\section{Acknowledgements}

It is a pleasure to acknowledge discussions on granites spanning more than three decades with my friend Professor Manuel Godinho. Professor Luís Neves is also thanked for his help in getting the manuscript published. I am grateful to numerous students at the University of St Andrews for their contributions over many years to the granite sample database. The pioneering research of the teams working on hot rock geothermal prospects in the UK during the 1970s and 80s is also acknowledged, and it is anticipated that their faith in the concept will soon be vindicated.

\section{References}

Anon (2010) - 2050 Pathways Analysis. London, HM Government.

Beardsmore, G. R. (2005) - Thermal Modeling of the Hot Dry Rock Geothermal Resource Beneath GEL99 in the Cooper Basin, South Australia. Proceedings World Geothermal Congress, Antalya, Turkey. 
Benfield, A. E. (1939) -Terrestrial heat flow in Great Britain Proceedings of the Royal Society of London. Series A, Mathematical and Physical Sciences; 173, 428-450.

Clark, C. D., D. J. A. Evans, et al. (2004) - Map and GIS database of glacial landforms and features related to the last British Ice Sheet; Boreas 44(4), 359-375.

Fretwell, P. T., D. E. Smith, et al. (2008) - The Last Glacial Maximum British-Irish Ice Sheet: a reconstruction using digital terrain mapping. Journal of Quaternary Science; 23, 241-248.

Geodynamics. (2009) - Submission to the Senate Select Committee on Fuel and Energy. Retrieved 16 February 2010, from http://www.aph.gov.au/senate/Committee/fuelenergy_ctte/submissions/sub0106.pdf.

Hurtig, E., V. Cermak, et al. (1992) - Geothermal atlas of Europe, H. Haack Verlagsgessellschaft $\mathrm{mbH}$ und Geogr.-Kartogr. Anstalt, Gotha.

Lambeck, K. (1995) - Late Devensian and Holocene shorelines of the British Isles from models of glacio-isostatic rebound. Journal of the Geological Society; 152, 437-448.

Lee, M. K. (1986) - Heat flow. Hot Dry Rock. R. A. Downing and D. A. Gray, British Geological Survey; 21-41.

Majorowic, J., J. Safanda, et al. (2008) - Heat flow variation with depth in Poland: evidence from equilibrium temperature logs in 2.9-km-deep well Torun-1. International Journal of Earth Science; 97, 307-315.

Majorowicz, J. and S. Wybraniec (2010) - New terrestrial heat flow map of Europe after regional paleoclimatic correction application. Int J Earth Sci (Geol Rundsch).

MIT (2006) - The Future of Geothermal Energy: Impact of Enhanced Geothermal Systems (EGS) on the United States in the 21st Century, Massachusetts Institute of Technology.

Nitsch, J. (2008) - Further development of the "Strategy to increase the use of renewable energies" within the context of the current climate protection goals of Germany and Europe. Retrieved 4/11/2010, 2010, from http://www.erneuerbare-energien.de/inhalt/42726/42455/.

Pollack, H. N. (1982) - The heat flow from continents. Annual Review of Earth and Planetary Sciences; 10, 459-481.

Stephens, W. E. and A. N. Halliday (1984) - Geochemical contrasts between late Caledonian granitoid plutons of northern, central and southern Scotland. Transactions Royal Society Edinburgh: Earth Science; 75, 259-273.

Webb, P. C. and G. C. Brown (1984) - The Eastern Highlands granites: heat production and related geochemistry. Investigation of the geothermal potential of the UK. Keyworth, British Geological Survey, 77pp.

Wheildon, J., G. King, et al. (1984) - The Eastern Highlands granites: heat fow, heat production and model studies. Investigation of the geothermal potential of the UK. Keyworth, British Geological Survey; 77pp.

Wheildon, J. and K. E. Rollin (1986) - Heat flow. Geothermal Energy: The potential in the UK. R. A. Downing and D. A. Gray, British Geological Survey; 8-20.

Wyborn, D. (2010) - Update of Development of the Geothermal Field in the Granite at Innamincka, South Australia. Proceedings World Geothermal Congress, Bali, Indonesia. 